\title{
Investigation on the capacity of the factors of the Clinical Dimensional Personality Inventory 2 for identifying people with substance dependence
}

\author{
André Pereira Gonçalves; Ana Paula Salvador; Lucas de Francisco Carvalho
}

How to cite this article:

Pereira Gonçalves, A., Salvador, A., P., \& Carvalho, L., de F. (2021). Investigation on the capacity of the factors of the Clinical Dimensional Personality Inventory 2 for identifying people with substance dependence. Acta Colombiana de Psicología, 24(1), 121-129. https://www.doi.org/10.14718/ACP.2021.24.1.11

Recibido, abril 24/2019; Concepto de evaluación, abril 04/2020; Aceptado, junio 01/2020

\author{
André Pereira Gonçalves1 \\ ORCID: 0000-0002-2470-4040 \\ Universidade São Francisco, Campinas, São Paulo, Brazil. \\ Ana Paula Salvador \\ ORCID: 0000-0001-5277-1657 \\ Universidade São Francisco, Campinas, São Paulo, Brazil. \\ Lucas de Francisco Carvalho \\ ORCID: 0000-0002-3274-9724 \\ Universidade São Francisco, Campinas, São Paulo, Brazil.
}

\begin{abstract}
The study aimed to verify the discriminant capacity of the factors of the Clinical Dimensional Personality Inventory 2 (IDCP-2) in the identification of people with substance dependence, as well as to compare this capacity with another instrument that evaluates pathological traits, the Personality Inventory for DSM-5 (PID-5). The sample was composed of 253 adults distributed in three groups: community sample, represented by 110 individuals with ages between 20 and 66 years $(M=32.3 ; S D=10,1), 71.8 \%$ women; subclinical, 119 individual aged from 18 to $63(M=30.4 ; S D=8.34), 61.3 \%$ women; clinical, 24 individual with ages between 19 and $59(M=36,4 ; S D=11.2), 83.3 \%$ men. Two scales for substance dependence identification were administered (AUDIT and ASSIST), IDCP-2, and PID-5. Findings indicated that IDCP-2 is capable of discriminating between groups, mainly the extreme ones (i.e., clinical sample versus community sample). Moreover, similar discriminant capacity between IDCP-2 and PID-5 was observed. These findings are preliminary evidence that the IDCP-2 factors can identify people with substance dependence, with Hopelessness being the leading factor in the assessment of substance dependents.

Keywords: psychological assessment; public health; drug addiction.
\end{abstract}

\footnotetext{
${ }^{1}$ Author's address: R. Waldemar César da Silveira, 105 - Jardim Cura D'ars, Campinas - SP, 13045-510; phone number: +1 55 35 992473310; e-mail: andregoncalvespsi@gmail.com
} 


\title{
Investigación de la capacidad de los factores del Inventario Dimensional Clinico de Personalidad 2 para discriminar personas con dependencia de sustancias
}

\begin{abstract}
Resumen
El objetivo de este estudio fue verificar la capacidad de los factores del Inventario Dimensional Clínico de la Personalidad-2 (IDCP-2) en la identificación de personas con dependencia química, así como comparar su capacidad discriminatoria con otro instrumento que evalúa rasgos patológicos, el Personality Inventory for DSM -5 (PID-5). La muestra contó con 253 personas divididas en tres grupos: población general, con 110 personas con edades entre 20 y 66 años $(M=32.3, D P=10.1)$ y $71,8 \%$ del sexo femenino; subclínico, con 119 individuos con edades entre 18 y 63 años $(M=30,4, D P=8,34)$ y $61,3 \%$ del sexo femenino; clínico, con 24 participantes siendo $83,3 \%$ del sexo masculino y con edades entre 19 y 59 años $(M=36,4, D P=11,2)$. Se aplicaron dos instrumentos para la identificación de la dependencia química (AUDIT y ASSIST), además del IDCP-2 y el PID-5. Los resultados indicaron que los factores utilizados del IDCP-2 son capaces de diferenciar los grupos, principalmente los extremos (clínico y población general). Además, se observó que el IDCP-2 posee capacidad predictiva de la dependencia química similar al PID-5. De esta manera, los hallazgos se configuran como evidencias preliminares de que los factores del IDCP-2 son capaces de identificar personas con dependencia química, siendo Desesperanza el factor principal en la evaluación de los dependientes químicos.

Palabras clave: evaluación psicológica; salud pública; dependencia química.
\end{abstract}

\section{Introduction}

Drug use and drug abuse are increasingly common terms in modern society, generating concerns and demands in the area of public health (Merz, 2018). The pathological extreme of drug use concerns drug addiction. According to the World Health Organization (WHO, 2015), substance dependence refers to behavioral, cognitive and physiological phenomena that are caused by the repeated use of substances, including a desire for use, difficulties in controlling it even when facing the consequences, a higher priority given to drug use than to other activities and obligations, tolerance, and physical abstinence. The etiology of substance dependence is related to social (e.g., socioeconomic status), biological (e.g., genetic), interpersonal relationships (e.g., family conflicts), and psychological characteristics (e.g., personality traits) (Frisher, Crome, Macleod, Bloor, \& Hickman, 2007; Goode, 2007; Nakhaee \& Jadidi, 2009).

The literature indicates specific personality traits typically increased in people diagnosed with substance dependence (Littlefield \& Sher, 2016). For instance, people with this diagnosis are prone to present high levels of hopelessness, depression, superiority, dominance, callousness, anxiety, impulsivity, and manipulation traits (APA, 2013; Bornovalova, Lejuez, Daughters, Rosenthal, \& Lynch, 2005; Kotov et al., 2017). Among these traits, impulsivity and anxiety seem to be the most commonly observed pathological traits in people with substance dependence (Chapman \& Cellucci, 2007; Feingold, Weiser, Rehm, \& Lev-Ran, 2016; Grant et al., 2004; Kotov, Gamez, Schmidt, \& Watson, 2010;
Loree, Lundahl, \& Ledgerwood, 2015; Marín-Navarrete et al., 2018; Verdejo-García, Lawrence, \& Clark, 2008).

Assessment measures that evaluate pathological traits should encompass traits typically identified in people with substance dependence. The Clinical Dimensional Personality Inventory (Carvalho \& Primi, 2015), currently in its second version (IDCP-2; Carvalho \& Primi, in press) and the focus of this study, is a self-report scale for assessing pathological traits, composed of 206 items that must be answered on a four-point Likert scale. The scale was developed to be used in the clinical context, and its recommended for establishing the personality profile of the patient (Carvalho, 2019). The IDCP-2 is composed of 12 dimensions, namely: dependence, aggressiveness, mood instability, eccentricity, need for attention, grandiosity, distrust, isolation, criticism avoidance, self-sacrifice, conscientiousness, and inconsequence, which are divided into 47 factors. The psychometric properties of the factors of these dimensions suggested the suitability of the scale for assessing pathological traits (e.g., Carvalho, Sette \& Ferrari, 2016; Carvalho \& Sette, 2017; Carvalho \& Silva, 2016).

Although studies have been conducted to investigate the discriminant ability of IDCP-2 for specific conditions (e.g., borderline personality disorder, dependent personality disorder, bipolar disorder; Carvalho \& Pianowski, 2019a; 2019b; Carvalho, Painwoski, \& Gonçalves, 2018), no studies were found investigating its discriminant capacity for people with substance dependence. However, based on the literature (APA, 2013; Bornovalova et al., 2005; Kotov et al., 2017; Moraleda-Barreno, Díaz-Batanero, PérezMoreno, Gómez-Bujedo, \& Lozano, 2018), it is possible to identify the conceptual relevant IDCP-2 factors for this 
purpose: Anxious Concern, Hopelessness, Superiority, Dominance, Indifference, Anxiety, Depression, Risk-taking, Deceitfulness, and Impulsivity. Although these factors lack empirical evidence on substance dependence, previous studies found sound psychometric properties for them (Carvalho, 2018; Carvalho \& Sette, 2017; 2015; Carvalho et al., 2016; Carvalho \& Silva, 2016).

This study aimed to investigate the capability of IDCP-2 factors to identify people with substance dependence, as well as to examine their discriminant capacity in comparison to the Personality Inventory for DSM - 5 (PID-5; Krueger, Derringer, Markon, Watson \& Skodol, 2011), a well-recognized scale in the field.

Three hypotheses were formulated:H1) the IDCP-2 factors should be able to discriminate the participants according to the level of substance dependence, especially the extreme groups (i.e., clinical group and general population group); H2) the factors representing the impulsiveness and anxiety traits should be the most discriminant (Bornovalova et al., 2005; Loree et al., 2015; Verdejo-García et al., 2008); and H3) the IDCP-2 factors should present a discriminant capacity for substance dependence superior or similar to the facets of PID-5.

\section{Method}

\section{Participants}

This is a quantitative study with correlational design (Creswell \& Creswell, 2017). The sample was composed of 253 adults from the five regions of Brazil and selected by convenience, with $74.3 \%$ of the participants residing in the Southeast region. The sample was divided into three groups, namely, the group composed of people without a clinical diagnosis of substance dependence and who did not reach the cutoff in AUDIT and ASSIST (general population group); the risk group for substance dependence, composed of people without a clinical diagnosis of substance dependence, but who reached the cutoff in AUDIT and ASSIST (subclinical group); and the group of people with a clinical diagnosis of substance dependence (clinical group). Table 1 presents the main characteristics of the sample groups.

\section{Measures}

The Alcohol, Smoking and Substance Involvement Screening Test(ASSIST; Henrique, Micheli, Lacerda, Lacerda \& Formigoni, 2004). It is a structured questionnaire consisting of eight items on the use of psychoactive substances, such as tobacco, alcohol, marijuana, cocaine, stimulants, sedatives, inhalants, hallucinogens, and opiates. ASSIST evaluates the frequency of substance use, problems arising from use, concern about use by people close to you, impairment in performing tasks, difficulties to be abstinent, compulsion to use, and use by the injectable route. The score ranges from 0 to 20. Evidence indicates ASSIST as a psychometrically sound scale (Henrique et al., 2004). In our study, the reliability estimate was equal to .74 (Cronbach's alpha).

Alcohol Use Disorders Identification Test (AUDIT; Mendéz, 1999) AUDIT was developed by WHO as a screening tool for alcohol risk use. It consists of 10 items, whose total score ranges from 0 to 40 . Evidence indicates AUDIT as a psychometrically sound scale (Lima et al., 2005; Santos, Gouveia, Fernandes, Souza, \& Grangeiro, 2012). In this study, the reliability estimate was equal to.79.

Clinical Dimensional Personality Inventory - 2 (IDCP-2; Carvalho \& Primi, in press) The IDCP-2 is a self-report scale to measure pathological traits, developed in Brazil. It's an updated version of the IDCP (Carvalho \& Primi, 2015), based on PD models (e.g., APA, 2013; Clark, 1990; Krueger et al., 2011; Millon, 2011; Shedler \& Westen, 2004). The IDCP-2 is composed of 206 items distributed in 12 dimensions, with a 4-point Likert-type response scale (1 = "has "nothing to do with me" and" 4 = "has "a lot to do with me"). Previous studies indicated the validity of IDCP2 factors (e.g. Carvalho, Pianowski, Silveira, Bacciotti, \& Vieira, 2016; Carvalho et al., 2016; Carvalho \& Sette, 2017; Carvalho \& Silva, 2016).

Table 1.

Descriptive statistics of the sample groups

\begin{tabular}{ccc}
\hline General Population & Subclinical & Clinical \\
\hline$n=110$ & $n=119$ & $n=24$ \\
$71.8 \%$ Female & $61 ., 3 \%$ Female & $83.3 \%$ Male \\
Age between 20 and 66 & Age between 18 e 63 anos & Age between 19 e 59 \\
$(M=32.3 ; S D=10.1)$ & $(M=30.4 ; S D=8.34)$ & $(M=36.4 ; S D=11.2)$ \\
& & $25 \%$ Basic \\
$58.2 \%$ Postgraduate & $58.9 \%$ Graduated and Postgraduate & $20.8 \%$ High School \\
& & $12.5 \%$ College student \\
$55.5 \%$ Single & $65.4 \%$ Single & $41.7 \%$ Single \\
$14.5 \%$ Psychiatric Treatment & $37.8 \%$ Psychiatric Treatment & $58.3 \%$ Psychiatric Treatment \\
\hline
\end{tabular}


For this study, the IDCP-2 factors associated with substance dependence were selected, based on the literature (APA, 2013; Belcher, Volkow, Moeller, \& Ferré, 2014; Kotov et al., 2017; Moraleda-Barreno et al., 2018). The factors selected were: Anxious worry, Hopelessness, Superiority, Dominance, Indifference, Anxiety, Depression, Risk-taking, and Deceitfulness. The Risk-taking factor was administered in this study as an indicator of the impulsivity trait. The reliability for internal consistency ranged between .84 (Anxious worry and Indifference factors) and .92 (Depression and Risk taking factors)

Personality Inventory for DSM-5 (PID-5; Krueger et al., 2011). The PID-5 is a self-report scale that measures 25 facets of maladaptive personality traits described in section III of the DSM-5, which can be combined into five domains. The items should be responded on a 4-point Likert scale. Studies support the psychometric properties of PID-5, with Cronbach's alphas ranging from 0.72 to 0.96 (median 0.86) (Krueger et al., 2011).

The following facets, based on previous literature were selected (APA, 2013; Belcher et al., 2014; Kotov et al., 2017; Moraleda-Barreno et al., 2018): Irresponsibility, Deceitfulness, Manipulativeness, Risk-taking, Grandiosity, Anxiety, and Depression. The reliability by internal consistency varied between .74 (Risk-taking) and .84 (Depression).

\section{Procedure}

Data collection with the general population was performed online using Google Forms and invitations sent via social media (e.g., Facebook). Data collection with patients diagnosed with substance dependence was conducted at a drug addiction recovery clinic. Participants took about 30 minutes to complete the survey. Protocols for people under 18 and incomplete protocols were excluded. Data were extracted to the SPSS program for statistical analysis.

\section{Data Analysis}

A homogeneity test based on kurtosis and asymmetry was performed, with kurtosis values between 1 and -1 and asymmetry between 2 and -2 being acceptable (George $\&$ Mallery, 2010). Analysis of variance (ANOVA) was employed to compare groups in the factors of IDCP-2 and facets of PID-5. To verify the homogeneity assumption, the Levene test was used, which indicated the violation of the assumption for some comparisons. Although studies are demonstrating that ANOVA can be employed in cases where the normality of the data is not observed (Blanca Mena, Alarcón, Arnau Gras, Bono Cabré, \& Bendayan, 2017), it was decided to use Welch's ANOVA, a variation of the classic ANOVA that can be applied for cases in which homogeneity is violated (Moder, 2007; 2010). Post-hoc analysis (Tukey method) was also performed to identify groups with significant differences. Two logistic regression analyzes were conducted (enter method). The first included the IDCP-2 factors and demographic variables sex, years of education, and age as independent variables, and the diagnosis of substance dependence as the dependent variable. The second was conducted with the PID-5 facets and the demographic variables as independent variables and the diagnosis as the dependent variable. It was chosen to conduct the two regression analyzes separately since the IDCP-2 factors with the PID-5 facets generated multicollinearity.

\section{Ethical aspects}

Prior contact was made with the rehabilitation clinic for data collection approval. The project was submitted to the Research Ethics Committee of Universidade São Francisco, being approved under CAAE 84826218.3.0000.5514. The study followed the guidelines and regulatory standards for research involving humans, based on Resolution No. 466, of December 12, 2012 (Ministério da Saúde \& Conselho Nacional da Saúde, 2012).

\section{Results}

The assumptions for conducting ANOVA, i.e., independent samples, the similar variance between groups, and distribution close to normal were achieved, according to the criteria presented in the literature (George \& Mallery, 2010). The Hopelessness factor presented kurtosis slightly higher than the threshold (kurtosis $=1.25$ ). Levene's test indicated that most of the factors in this study did not show homogeneity of variance. Only Anxious Concern, Dominance, Indifference, and Anxiety factors showed homogeneity of variance. Empirical evidence indicates that, even in these cases, it is possible to use ANOVA (Blanca Mena et al., 2017). However, it was chosen to use Welch's ANOVA, a variation of the classic ANOVA, that can be employed for cases in which homogeneity is violated (Moder, 2007; 2010).

Analyzes of variance were performed to verify the differences between the sample groups in the IDCP-2 factors. All factors showed statistically significant differences: Anxious Worry $[F(2,67)=16.448 ; p<.001]$, Hopelessness $[F(2,61)=18.330 ; p<.001]$, Superiority $[F$ $(2,59)=9,200 ; p<.001]$, Dominance $[F(2.63)=4.704$; $p=.01]$, Indifference $[F(2,63)=10,198 ; p<.001]$, Anxiety $[F(2.69)=11.631 ; p<.001]$, Depression $[F(2,65)=7.838$; $p<.001]$, Risk-taking $[F(2,57)=27.358 ; p<.001]$, and Deceitfulness $[F(2.61)=20.003 ; p<.001]$. In order to 
Table 2.

ANOVA's Post Hoc test-sample groups and IDCP-2 factors

\begin{tabular}{|c|c|c|c|c|c|c|c|}
\hline \multirow[b]{2}{*}{ Groups } & \multicolumn{3}{|c|}{ Anxious Worry } & \multicolumn{2}{|c|}{ Hopelessness } & \multicolumn{2}{|c|}{ Superiority } \\
\hline & 1 & 2 & 3 & 1 & 2 & 1 & 2 \\
\hline General population $(\mathrm{n}=110)$ & $2.22(.78)$ & & & $1.31(.54)$ & & $1.57(.59)$ & \\
\hline Subclinical $(\mathrm{n}=119)$ & & $2.60(.77)$ & & & $1.78(.88)$ & $1.78(.83)$ & \\
\hline \multirow[t]{2}{*}{ Clinical $(n=24)$} & & & $3.11(.71)$ & & $2.09(.85)$ & & $2.44(1.0)$ \\
\hline & \multicolumn{3}{|c|}{ Risk-taking } & \multicolumn{2}{|c|}{ Indifference } & \multicolumn{2}{|c|}{ Anxiety } \\
\hline Groups & 1 & 2 & 3 & 1 & 2 & 1 & 2 \\
\hline General population $(\mathrm{n}=110)$ & $1.24(.40)$ & & & $1.47(.62)$ & & $2.29(.96)$ & \\
\hline Subclinical $(\mathrm{n}=119)$ & & $1.70(.73)$ & & $1.67(.65)$ & & & $2.81(.84)$ \\
\hline \multirow[t]{2}{*}{ Clinical $(\mathrm{n}=24)$} & & & $2.18(.89)$ & & $2.16(.71)$ & & $3.00(.76)$ \\
\hline & \multicolumn{3}{|c|}{ Deceitfulness } & \multicolumn{2}{|c|}{ Dominance } & \multicolumn{2}{|c|}{ Depression } \\
\hline Groups & 1 & 2 & 3 & 1 & 2 & 1 & 2 \\
\hline General population $(\mathrm{n}=110)$ & $1.37(.44)$ & & & $2.05(.72)$ & & $1.65(.78)$ & \\
\hline Subclinical $(\mathrm{n}=119)$ & & $1.70(.61)$ & & 2.27 & $2.27(.72)$ & 2.03 & $2.03(.99)$ \\
\hline Clinical $(n=24)$ & & & $2.10(.65)$ & & $2.51(.79)$ & & $2.26(.88)$ \\
\hline
\end{tabular}

Note. $\alpha=.05$; intragroups p-value was non-significant (.089-1.0); inside brackets the standard deviation values.

find out which groups differed, Table 2 presents Tukey's post hoc analysis.

The groups were discriminated with the Anxious Worry, Risk-taking, and Deceitfulness factors, with the clinical group presenting higher means and the general population group with lower means. The factors Hopelessness and Anxiety were able to discriminate the clinical and subclinical group from the general population. The factors Superiority and Indifference differentiated the clinical group, which had higher means, the subclinical group, and the general population. In the Dominance and Depression factors, two groups were separated, general population and clinical groups, with the latter presenting higher means.

In order to verify the predictive capacity of the IDCP-2 factors for substance dependence, logistic regression was employed with only the general population $(n=110)$ and clinical $(n=24)$ groups, as can be seen in Table 3. In the first model, the IDCP-2 factors were used as independent variables and a dichotomous variable, presence or no presence of substance dependence, was the dependent variable. A second regression model was conducted only with the independent variables that presented a significant single contribution in the first model.

Model 1 was able to predict $77 \%$ of the group variable. The variables with statistically significant contributions were Sex and the Hopelessness factor of IDCP-2. This model was able to correctly identify $82.6 \%$ of people in the clinical group and $100 \%$ of people in the general population group. Model 2, including variables with a single contribution in the first model, was able to predict $56 \%$ of the group variable. This model was able to identify $58.3 \%$ of the clinical group and $97.3 \%$ of the non-clinical group, indicating that the first model provides information that improves the ability to identify the groups. Table 4 presents the logistic regression analysis with the PID-5.

The model with the PID-5 facets as independent variables was able to predict $76 \%$ of the group variable, similar to what was observed with the IDCP-2 factors. In this model, sex was also significant, in addition to the Anxiety facet. This 
IDCP-2 and substance dependence

126

Table 3.

Logistic regression analysis - IDCP-2 factors and dichotomous variable of substance dependence

\begin{tabular}{|c|c|c|c|c|c|}
\hline \multicolumn{6}{|c|}{ Model 1} \\
\hline IDCP-2 & $B$ & EP & $p$ & $\operatorname{Exp}(B)$ & Nagelkerke $r^{2}$ \\
\hline Anxious Worry & .04 & .96 & .97 & 1.04 & .77 \\
\hline Hopelessness & 2.31 & 1.07 & 0.03 & 10.11 & \\
\hline Superiority & .65 & .73 & .37 & 1.91 & \\
\hline Dominance & -.50 & .86 & .56 & .61 & \\
\hline Indifference & .14 & .78 & .86 & 1.15 & \\
\hline Anxiety & -.27 & .88 & .76 & .76 & \\
\hline Depression & -.06 & 1.01 & .95 & .94 & \\
\hline Risk-taking & 1.31 & .83 & .11 & 3.69 & \\
\hline Deceitfulness & 1.09 & .97 & .26 & 2.97 & \\
\hline Age & .04 & .05 & .37 & 1.05 & \\
\hline Sex & 2.79 & 1.24 & .02 & 16.24 & \\
\hline Years of education & -1.01 & .74 & .17 & .36 & \\
\hline \multicolumn{6}{|c|}{ Model 2} \\
\hline & $B$ & EP & $p$ & $\operatorname{Exp}(B)$ & Nagelkerke $r^{2}$ \\
\hline Hopelessness & 2.29 & .54 & $p<.01$ & 18.08 & .56 \\
\hline Sex & 4.07 & 1.03 & $p<.01$ & 15.43 & \\
\hline
\end{tabular}

Note. In bold, the significant independent variables in the model.

Table 4.

Logistic regression analysis - PID-5 factors and dichotomous variable of substance dependence

\begin{tabular}{cccccc}
\hline PID-5 & $B$ & S.E & $p$ & Exp $(B)$ & Nagelkerke $r^{2}$ \\
\hline Irresponsibility & .11 & .13 & .43 & 1.11 & \\
Deceitfulness & .03 & .11 & .78 & .97 & \\
Manipulativeness & .15 & .18 & .39 & 1.17 & \\
Risk-taking & .18 & .09 & .06 & 1.19 & .76 \\
Grandiosity & .14 & .12 & .24 & 1.15 & .76 \\
Anxiety &. $\mathbf{2 0}$ &. $\mathbf{1 0}$ &. $\mathbf{0 4}$ & $\mathbf{1 . 2 2}$ & \\
Depression & .03 & .05 & .55 & 1.03 & \\
Age & .08 & .05 & .13 & 1.08 & \\
Sex & $\mathbf{2 . 0 2}$ & $\mathbf{. 9 3}$ &. $\mathbf{0 3}$ & $\mathbf{7 . 5 5}$ & \\
Years of education & -1.17 & .63 & .06 & .309 & \\
\hline & & Model 2 & & & \\
\hline Anxiety & $B$ & S.E & $p$ & Exp $(B)$ & Nagelkerke $r^{2}$ \\
Sex & .20 & .05 & $p<.01$ & 1.22 & \\
\hline
\end{tabular}

Note. in bold, the significant independent variables in the model. 
model was able to correctly identify $78.3 \%$ of people in the clinical group, and $100 \%$ of people in the general population group. Model 2, including only variables significant in the first model, was able to predict $50 \%$ of the group variable. This model was able to correctly identify $54.2 \%$ of people in the clinical group and $95.5 \%$ in the non-clinical group.

\section{Discussion}

This study aimed to verify the contribution of the IDCP-2 self-report scale in the identification of people with substance dependence and to compare their predictive capacity with PID-5. The findings of this study confirmed the initial hypotheses: H1) the IDCP-2 factors were capable of differentiating the groups, especially the extreme groups, i.e., general population and clinical group; H2) the Risk-taking factor, representing the impulsiveness trait, and the two factors related to anxiety (Anxious Worry and Anxiety factors) were those with the best performance in discriminating groups; and, H3) similar results ( $r 2)$ were observed between IDCP-2 and PID-5 in the predictive capacity of substance dependence. The hypotheses are discussed in the following paragraphs.

The IDCP-2 factors were able to discriminate between the general population and the clinical group. These findings are in agreement with the literature that lists hopelessness, superiority, dominance, indifference, anxiety, depression, impulsivity, and manipulation as characteristics of drug addicts (APA, 2013; Kotov et al., 2017; Moraleda-Barreno et al., 2018). It was also observed that the Risk-taking factor, representing the impulsiveness trait in this study, and the factors Anxiety and Anxious Worry, showed greater differences between the general population and clinical groups. This finding confirms previous evidence indicating that Impulsiveness and Anxiety traits as the most relevant for discriminating people with substance dependence (Belcher et al., 2014; Ersche, Turton, Pradhan, Bullmore, \& Robbins, 2010; Grant et al., 2004; Lai, Cleary, Sitharthan, \& Hunt, 2015; Mitchell \& Potenza, 2014; Moraleda-Barreno et al., 2018;). These results confirm the $\mathrm{H} 1$ and $\mathrm{H} 2$ of our study.

As for the third hypothesis of this study $(\mathrm{H} 3)$, the predictive capacity for substance dependence on the IDCP-2 factors was similar to the capacity of the PID-5 facets. The findings suggest that the scores of IDCP-2 and PID-5 are capable of predicting, respectively, $77 \%$ and $76 \%$ of the sample groups. In IDCP-2, the only significant factor in the model was Hopelessness. This factor concerns feelings of sadness, discouragement, and suicidal thoughts (Carvalho \& Primi, in press), representing traits frequently identified in drug addicts (Baines, Jones, \& Christiansen, 2016; Karamat \& Ahmed, 2015). Although coherent, it was expected that other factors of IDCP-2 would show discriminant capacity with a similar or higher weight to the Hopelessness factor. Future studies should verify whether the findings of the present research are replicated. The PID-5 presented only the Anxiety facet as significant in the regression analysis. This facet represents the exaggerated concern about the possibility of uncomfortable events in the future that may or may not happen (Krueger et al., 2011). Studies have found that groups of drug addicts have higher levels of anxiety compared to the general population (Belcher et al., 2014, Grant et al., 2004; Lai et al., 2015).

The findings of this study are preliminary evidence indicating that the IDCP-2 factors are capable of identifying people with substance dependence. It was observed that Risktaking, Anxious Worry, and Anxiety factors were the best for discriminating people with substance dependence from individuals who reported not having this diagnosis. These factors were also discriminant to correctly identify people without a diagnosis of substance dependence but were characterized as a risk group by the AUDIT and ASSIST scales.

The findings should be weighted according to the major methodological limitations of this study. First, the sample size of the groups was very distinct, the distribution of demographic variables was uneven (e.g., sex), and information was not accessible on the most used type of chemical substance and the form of administration (e.g., injectable, inhaled). Second, most of the clinical sample was being treated at a rehabilitation clinic, which may have mitigated responses to the scales. Third, attention is called on the use of the Risk-taking factor of IDCP-2, as representative of the impulsivity trait. Future studies should investigate the application of the IDCP-2 Impulsivity factor for this purpose. Although the findings of this study are promising, they should be considered as preliminary to the use of specific factors from IDCP-2 to identify people with substance dependence. Future studies must verify whether these findings are replicated in samples, especially designs with larger clinical samples.

\section{References}

American Psychiatric Association. (2013). Diagnostic and statistical manual of mental disorders (DSM-5). Washing-ton, DC: American Psychiatric Pub.

Baines, L., Jones, A., \& Christiansen, P. (2016). Hopelessness and alcohol use: the mediating role of drinking motives and outcome expectancies. Addictive behaviors reports, 4, 6569. https://doi.org/10.1016/j.abrep.2016.11.001

Belcher, A. M., Volkow, N. D., Moeller, F. G., \& Ferré, S. (2014). Personality traits and vulnerability or resilience to 
substance use disorders. Trends in cognitive sciences, 18(4), 211-217. https://doi.org/10.1016/j.tics.2014.01.010

Blanca Mena, M. J., Alarcón, R., Arnau Gras, J., Bono Cabré, R., \& Bendayan, R. (2017). Non-normal data: is ANOVA still a valid option?. Psicothema, 29(4), 552-557. https:// doi.org/10.7334/psicothema2016.383

Bornovalova, M. A., Lejuez, C. W., Daughters, S. B., Rosenthal, M. Z., \& Lynch, T. R. (2005). Impulsivity as a common process across borderline personality and substance use disorders. Clinical Psychology Review, 25(6), 790-812. https:// doi.org/10.1016/j.cpr.2005.05.005

Carvalho, L. D. F. (2018). Review study of the impulsiveness dimension of the Dimensional Clinical Personality Inventory. Universitas Psychologica, 17(1), 58-68. https:// dx.doi.org/10.11144/javeriana.upsy17-1.rsid

Carvalho, L. D. F. (2019). Avaliação dos transtornos da personalidade no Brasil: panorama geral e ferramentas disponíveis. In M. N. Baptista, M. Muniz, C. T. Reppold, C. H. S. S. Nunes, L. F. Carvalho, R. Primi, A. P. P. Noronha, A. G. Seabra, S. W. Wechsler, C. S. Hutz, \& L. Pasquali (Org.), Compêndio de Avaliação Psicológica. (1ed., pp. 569-579). Rio de Janeiro: Editora Vozes.

Carvalho, L. D. F., \& Pianowski, G. (2019a). Dependency, mood instability, and inconsequence traits for discriminating borderline personality disorder. Trends in psychiatry and psychotherapy, 41(1), 78-82. https://dx.doi. org/10.1590/2237-6089-2018-0010

Carvalho, L. D. F., \& Pianowski, G. (2019b). Differentiating borderline personality disorder and bipolar disorder through emotional dependency, emotional instability, impulsiveness and aggressiveness traits. The European Journal of Psychiatry, 33(2), 91-95. https://doi.org/10.1016/j. ejpsy.2019.03.001

Carvalho, L. D. F., Pianowski, G., \& Gonçalves, A. P. (2018). Dimensional Clinical Personality Inventory-2: investigating key factors on the assessment of dependent personality disorder. Psychology, Health \& Medicine, 24(6), 732-738. https://doi.org/10.1080/13548506.2018.1554254

Carvalho, L. F., Pianowski, G., Silveira, F. J., Bacciotti, J. T., \& Vieira, P. G. (2016). Eccentricity dimension of the Dimensional Clinical Personality Inventory: review and psychometric properties. Estudos de Psicologia, 21(4), 359-368. http://dx.doi.org/10.5935/1678-4669.20160035

Carvalho, L. F., \& Primi, R. (no prelo). Manual técnico do Inventário Dimensional Clínico da Personalidade 2 (IDCP2) e versão triagem (IDCP-triagem). São Paulo: Pearson.

Carvalho, L. D. F., \& Primi, R. (2015). Development and internal structure investigation of the Dimensional Clinical Personality Inventory. Psicologia: Reflexão e Crítica, 28(2), 322-330. http://dx.doi.org/10.1590/1678-7153.201528212

Carvalho, L. D. F., \& Sette, C. P. (2015). Review and verification of the psychometric properties of the mood instability dimension of the Dimensional Clinical Personality
Inventory. Acta Colombiana de Psicología, 18(2), 115-127. https://dx.doi.org/10.14718/ACP.2015.18.2.10

Carvalho, L. D. F., \& Sette, C. P. (2017). Revision of the criticism avoidance dimension of the dimensional clinical personality inventory. Estudos de Psicologia (Campinas), 34(2), 219231. https://doi.org/10.1590/1982-02752017000200004

Carvalho, L. D. F., Sette, C. P., \& Ferrari, B. L. (2016). Revision of the grandiosity dimension of the Dimensional Clinical Personality Inventory and verification of its psychometric properties. Trends in Psychiatry and Psychotherapy, 38(3), 147-155. https://doi.org/10.1186/s41155-016-0022-z

Carvalho, L. F., \& Silva, G. C. (2016). Review of the self-sacrifice dimension of the Clinical Dimensional Personality Inventory. Psicologia: Reflexão e Crítica, 29(6), 1-8. https://doi.org/10.1186/s41155-016-0022-z

Chapman, A. L., \& Cellucci, T. (2007). The role of antisocial and borderline personality features in substance dependence among incarcerated females. Addictive Behaviors, 32(6), 1131-1145. https://doi.org/10.1016/j.addbeh.2006.08.001

Clark, L. A. (1990). Toward a consensual set of symptom clusters for assessment of personality disorder. In: Butcher $\mathrm{JN}$, Spielberger CD, editors, Advances in personality assessment. (pp. 243-266). New Jersey: Lawrence Erlbaum Associates.

Creswell, J. W., \& Creswell, J. D. (2017). Research design: qualitative, quantitative, and mixed methods approaches (5th ed.). SAGE Publications.

Ersche, K. D., Turton, A. J., Pradhan, S., Bullmore, E. T., \& Robbins, T. W. (2010). Drug addiction endophenotypes: impulsive versus sensation-seeking personality traits. Biological Psychiatry, 68(8), 770-773. https://doi. org/10.1016/j.biopsych.2010.06.015

Feingold, D., Weiser, M., Rehm, J., \& Lev-Ran, S. (2016). The association between cannabis use and anxiety disorders: results from a population-based representative sample. European Neuropsychopharmacology, 26(3), 493-505. https://doi.org/10.1016/j.euroneuro.2015.12.037

Frisher, M., Crome, I., Macleod, J., Bloor, R., \& Hickman, M. (2007). Predictive factors for illicit drug use among young people. Home Office. https://pdfs.semanticscholar.org/fcb3 /8c9b9cf010b53c2f30aa135eb1094c5951ef.pdf

George, D., \& Mallery, M. (2010). SPSS for Windows Step by Step: A Simple Guide and Reference, 17.0 update (10a ed.) Boston: Pearson.

Goode, E. (2007). Theories of drug use. In McGraw Hill, Drugs in American Society (pp.55-58). Boston, Mass.

Grant, B. F., Stinson, F. S., Dawson, D. A., Chou, S. P., Dufour, M. C., Compton, W., ... \& Kaplan, K. (2004). Prevalence and co-occurrence of substance use disorders and independent mood and anxiety disorders: results from the national epidemiologic survey on alcohol and related conditions. Archives of General Psychiatry, 61(8), 807-816. https://dx.doi.org/10.1001/archpsyc.61.8.807 
Henrique, I. F. S., Micheli, D., Lacerda, R. B. D., Lacerda, L. A. D., \& Formigoni, M. L. O. D. S. (2004). Validação da versão brasileira do teste de triagem do envolvimento com álcool, cigarro e outras substâncias (ASSIST). Revista da Associação Médica Brasileira, 50(2), 199-206. https:// dx.doi.org/10.1590/S0104-42302004000200039

Karamat, M., \& Ahmed, S. (2015). Collective self-esteem and hopelessness among people with substance use. Pakistan Journal of Psychology, 46(2). https://search.proquest.com/ docview/1891725868?pq-origsite $=$ gscholar\&fromopenvie $\mathrm{w}=$ true

Kotov, R., Gamez, W., Schmidt, F., \& Watson, D. (2010). Linking "big" personality traits to anxiety, depressive, and substance use disorders: a meta-analysis. Psychological Bulletin, 136(5), 768-821. https://doi.org/10.1037/a0020327

Kotov, R., Krueger, R. F., Watson, D., Achenbach, T. M., Althoff, R. R., Bagby, R. M., ... \& Eaton, N. R. (2017). The Hierarchical Taxonomy of Psychopathology (HiTOP): a dimensional alternative to traditional nosologies. Journal of Abnormal Psychology, 126(4), 454-477. https://doi. org/10.1037/abn0000258

Krueger, R. F., Derringer, J., Markon, K. E., Watson, D., \& Skodol, A. E. (2011). Initial construction of a maladaptive personality trait model and inventory for DSM-5. Psychological Medicine, 42(9), 1879-1890. https://doi. org/10.1017/S0033291711002674

Lai, H. M. X., Cleary, M., Sitharthan, T., \& Hunt, G. E. (2015). Prevalence of comorbid substance use, anxiety and mood disorders in epidemiological surveys, 19902014: a systematic review and meta-analysis. Drug and Alcohol Dependence, 154, 1-13. https://doi.org/10.1016/j. drugalcdep.2015.05.031

Lima, C. T., Freire, A. C. C., Silva, A. P. B., Teixeira, R. M., Farrell, M., \& Prince, M. (2005). Concurrent and construct validity of the AUDIT in an urban Brazilian sample. Alcohol and Alcoholism, 40(6), 584-589. https://doi.org/10.1093/ alcalc/agh202

Littlefield,A. K., \& Sher, K. J. (2016). Personality and Substance Use Disorders. Oxford Handbooks Online. https://doi.org /10.1093/oxfordhb/9780199381678.001.0001

Loree, A. M., Lundahl, L. H., \& Ledgerwood, D. M. (2015). Impulsivity as a predictor of treatment outcome in substance use disorders: review and synthesis. Drug and Alcohol Review, 34(2), 119-134. https://doi.org/10.1111/dar.12132

Marín-Navarrete, R., Toledo-Fernández, A., VillalobosGallegos, L., Roncero, C., Szerman, N., \& Medina-Mora, M. E. (2018). Latent impulsivity subtypes in substance use disorders and interactions with internalizing and externalizing co-occurring disorders. Frontiers in Psychiatry, 9, 1-9. doi: $10.3389 /$ fpsyt.2018.00027

Mendéz, E. B. (1999). Uma versão brasileira do AUDIT (Alcohol Use Disorders Identification Test). Dissertação de Mestrado, Universidade Federal de Pelotas, Pelotas (RS).
Merz, F. (2018). United Nations Office on Drugs and Crime: World Drug Report 2017. 2017. SIRIUS-Zeitschrift für Strategische Analysen, 2(1), 85-86. https://doi.org/10.1515/ sirius-2018-0016

Millon, T. (2011). Disorders of personality: introducing a $D S M / I C D$ spectrum from normal to abnormal. New Jersey: Wiley.

Ministério da Saúde \& Conselho Nacional de Saúde. (2012). Resolução $\mathrm{n}^{\mathrm{o}}$ 466, de 12 de dezembro de 2012. Diretrizes e normas regulamentadoras de pesquisas envolvendo seres humanos. Diário Oficial da União [da] República Federativa do Brasil, 150(112). http://bvsms.saude.gov.br/ bvs/saudelegis/cns/2013/res0466_12_12_2012.html

Mitchell, M. R., \& Potenza, M. N. (2014). Addictions and personality traits: impulsivity and related constructs. Current Behavioral Neuroscience Reports, 1(1), 1-12. https://doi. org/10.1007/s40473-013-0001-y

Moder, K. (2007). How to keep the Type I Error Rate in ANOVA if Variances are Heteroscedastic. Austrian Journal of Statistics, 36(3), 179-188. https://doi.org/10.17713/ajs.v36i3.329

Moder, K. (2010). Alternatives to F-test in one way ANOVA in case of heterogeneity of variances (a simulation study). Psychological Test and Assessment Modeling, 52(4), 343353. https://www.psychologie-aktuell.com/fileadmin/download/ptam/4-2010_20101218/01_Moder.pdf

Moraleda-Barreno, E., Díaz-Batanero, C., Pérez-Moreno, P. J., Gómez-Bujedo, J., \& Lozano, O. M. (2018). Relations between facets and personality domains with impulsivity: new evidence using the DSM-5 Section III framework in patients with substance use disorders. Personality Disorders: Theory, Research, and Treatment. 9(5), 490-495. https:// doi.org/10.1037/per0000278

Nakhaee, N., \& Jadidi, N. (2009). Why do some teens turn to drugs? a focus group study of drug users' experiences. Journal of Addictions Nursing, 20(4), 203-208. https:// doi.org/10.3109/10884600903291158

Organização Mundial da Saúde - WHO. (2015). CID-10: Classificação Estatística Internacional de Doenças com disquete Vol. 3. Edusp.

Santos, W. S. D., Gouveia, V. V., Fernandes, D. P., Souza, S. S. B. D., \& Grangeiro, A. S. D. M. (2012). Alcohol use disorder identification test (AUDIT): exploring its psychometric parameters. Jornal Brasileiro de Psiquiatria, 61(3), 117123. https://doi.org/10.1590/S0047-20852012000300001

Shedler, J., \& Westen, D. (2004). Refining personality disorder diagnosis: integrating science and practice. American Journal of Psychiatry, 161(8), 1350-1365. https://doi. org/10.1176/appi.ajp.161.8.1350

Verdejo-García, A., Lawrence, A. J., \& Clark, L. (2008). Impulsivity as a vulnerability marker for substance-use disorders: review of findings from high-risk research, problem gamblers and genetic association studies. Neuroscience \& Biobehavioral Reviews, 32(4), 777-810. https://doi. org/10.1016/j.neubiorev.2007.11.003 